\title{
Editorial: Poverty and Mobility in England, 1600-1850
}

\author{
D A V I D H I T C H C O C K \\ Department of History, University of Warwick, Humanities Building, University \\ Road, Coventry, CV4 7AL, UK \\ David.Hitchcock@warwick.ac.uk
}
Good Master spare a farthing,
It is my daily cry,
But when I'm at the alehouse, no man so great as $\mathrm{I}^{1}$

1.

Within these pages you will find a 'jovial crew': rogues and vagabonds, the 'mad' and insane, gypsies, peddlers, poets, playwrights, pilgrims, rioters, convicts, constables, thieves, beggars, landed gentlemen, magistrates, and historians. When parliamentarians and projectors set out to proscribe mobility and legislate poverty in early modernity, a list of untrustworthy trades and professions not at all unlike this one frequently found its way into print and the statute book. The punishment for crimes of vagrancy could be severe, but thankfully 'historians' were not counted among the undeserving and mobile, nor would you find magistrates and landed gentlemen taken up, imprisoned, and whipped for a crime of movement. However, all three groups may well deserve some of John Locke's brand of draconian 'improvement'; historians in particular have taken little account of the lived experiences of the mobile poor until relatively recently. ${ }^{2}$ Once we finally took a hard look at our inherited, literature-driven typologies of 'rogues' and 'beggars', they disappeared in 'a storm of dust and lies.' ${ }^{3}$ However, the literary, visualised vagabond still has much to tell us, and interdisciplinary approaches to vagrancy in the past have emerged as the strongest method yet of reconstructing the character, history, and cultural perception of the mobile poor. These are methods which the articles in this collection use to full effect. ${ }^{4}$

This special issue of Rural History began life as a conference held at the University of Warwick in March of 2011 with the aim of addressing an enduring scholarly lacuna: the social and cultural history of vagrancy in England from around 1600 until 1850. The papers were novel, showcasing a range of innovative and different approaches to the history of vagrancy in England; including art history, poetry and criticism, cultural geography, social and medical history, and the use of massive digital datasets. While 
the primacy of the historical archive remains undisputed in social history, scholars are confronted with the task of recovering experiences on the margins both of societies and of the records created by them. The methods used to access these hidden histories are increasingly sophisticated and interdisciplinary.

This introduction will offer a short synopsis of the legislative and social history of poverty and mobility in England, with further reading suggested in the notes. It will then explain the content and aims of the five articles, which are wide ranging in their material, periodisation, and methods. Historiographically, poverty and mobility emerged independently as sub-disciplines of social history in the latter half of the twentieth century, largely from the 1970s..$^{5}$ The 1980 s saw an explosion of monographs on the social history of England, particularly for the early modern period, and the publication of seminal texts on vagrancy and poverty, including A. L. Beier's Masterless Men and Paul Slack's Poverty and Policy. ${ }^{6}$ Despite this burgeoning scholarly interest, vagrants still remain 'shadowy figures' almost thirty years after Beier characterised them this way. ${ }^{7}$ The opacity of vagrant lives and experiences in the past owes much to the relative paucity of detailed primary sources for certain periods, particularly after 1662 and before 1744 , and for certain regions. ${ }^{8}$ For instance, the printed material on vagrancy is largely dominated by London's experience of poverty and mobility. The archives of Bridewell and the city's other penal institutions have good rates of record survival, so that London's eighteenth-century vagrancy problem is accordingly both well documented and well studied. ${ }^{9}$

2.

So what did it mean to be a vagrant and a 'lewd and idle rogue'? To contemporaries, vagrancy was the quintessential crime of those undeserving of relief: to be labelled a vagrant meant that one was indolent, unwilling to work, prone to begging and wandering, and to disruption of the peace. A vagabond could be a stranger in many parish communities, a patron of unlicensed alehouses, an itinerant peddler, a deserting soldier or illicit gamester, a fleeing husband, perhaps even a palm reader or forger, at least if one believes published contemporary opinions. Vagrancy, first and foremost, was a crime of status. Vagrants were generally labelled and prosecuted as such, based on a wide variety of casual indicators: these could include wandering, begging, being able-bodied yet idle, travelling the roads without a purpose, proffering peddling and palmistry, and a range of other categories. Sometimes simply being a stranger and poor would suffice. Moreover, legislation against vagrants inevitably concentrated on their wasted potential as labourers, enjoining or forcing them to work through committal to houses of correction and later workhouses. Legislation against vagrancy and idle wandering in England dates back to the reign of Edward III, but most histories of vagrancy law begin in earnest with the Elizabethan statute of 1572, which repealed all previous laws against vagrancy and instituted a new code. ${ }^{10}$ Elizabethan vagrants caught and convicted were to be whipped and burned through the ear, and repeated offences were felonies without benefit of clergy. These draconian measures stem from rising fears about a swelling tide of masterless and idle persons, who had taken to the roads in search of subsistence. However, the statutory 
basis for settlement law and the parish-based relief of vagrancy stems from this Act and from its immediate successors, which included revisions in 1597, 1601, and 1604. ${ }^{11}$

The Elizabethan statutes also provided the codified definition of vagrancy which remained the centerpiece of all subsequent legislation which dealt with 'idle wandering' until late in the nineteenth century:

All wandering persons and common Labourers being persons able in bodye using loytering and refusing to worke for such respectable Wages as is taxed or commonly gyven in such Partes where such persons do or shall happen to dwell or abide, not having lyving otherwise to maynteyne themselves.

This definition included a standard list of colourful characters such as minstrels, tinkers, bearwards, and so on. ${ }^{12}$ It was deliberately hazy, and while the Tudor statutes ostensibly distinguished between deserving and undeserving paupers, the legislative assumption was that 'a man honestly seeking work could find it in his own parish', at least until $1662 .{ }^{13}$ Statutory poor relief was again revised and updated after the civil war, most importantly in 1662 with the Settlement Act, which dealt explicitly with where paupers belonged in an effort to curb subsistence mobility and vagrancy. It was this statute which dealt with mobile and seasonal work, and which set up a system of certificates to monitor the traffic of casual labourers. Once again, an explicitly 'Tudor' definition of deserving poor and undeserving rogues was employed, which included key terms such as 'sturdy beggar' and 'incorrigible rogue'. ${ }^{14}$ A reward of two shillings was instituted for the apprehension of vagrants by constables, and the punishment of transportation was introduced for those deemed incorrigible rogues. However, the Act's effects on plebeian mobility were far more wide ranging, and the late seventeenth century witnessed a significant increase in pauper migration in search of work. ${ }^{15}$

There is also an important distinction to be drawn between 'idle wandering' vagrants in early modern England, and the mobile poor, a distinction often without social difference in the lived experience of paupers, but one enshrined in contemporary legislation governing both subsistence migration and vagrancy. Parish settlement law and seventeenth-century legislation controlling subsistence migration could affect vagrants, and vagrancy laws could be used against migrants in search of work. However, a contemporary definition of the mobile, labouring poor existed via exclusion and was proven in Quarter sessions through documentation. Servant passes, settlement papers, and passes for returning soldiers all allowed the bearer significant personal mobility and even casual assistance from parish officials on their travel route. But the right to live and 'belong' to a parish and to be settled there could be just as contentious and exclusionary as charges of vagrancy. ${ }^{16}$ Charges of 'Lyving at one's own hands', a form of prosecution for idleness, were heard against servants in husbandry and other rural labouring occupations well into the eighteenth century, and punishments often resembled those meted out to identified vagrants. ${ }^{17}$

The eighteenth century also saw its share of important legislative developments concerning vagrants. In 1700 the Vagrant Costs Removal Act mandated that counties instead of the parishes had to accept the charge of passing vagrants to their parish of settlement, which in effect encouraged parishes to 'export' the chargeable poor under the guise of vagrancy proceedings, in order to shift the fiscal burden to the county. ${ }^{18}$ In 
1714 another act was passed which set up the system which would deal with vagrants for the rest of the eighteenth century. ${ }^{19}$ It detailed exactly who was to be considered, and passed, as a vagrant in an effort to stop parish abuses of the law. The Act also outlined the procedure by which vagrants were to be dealt with and sent to their parish of settlement: they would be apprehended and appear before a Justice of the Peace, where a deposition and settlement examination would be taken in an effort to determine their history and parish of settlement. The Justice would then issue a vagrant pass and order all constables along the route to their settlement to assist in the conveyance of the vagrant, and the settlement examination would be filed in the Quarter Sessions. The discretionary powers of Justices were also expanded. They could commit any 'unreformed' or 'dangerous' vagrants to houses of correction or hard labour, and could summarily punish any vagrant with whipping and imprisonment.

Vagrancy legislation was thoroughly amended again in 1744 and in 1792, but the essential operation of the system remained the same from 1714. The main changes in 1744 and 1792 dealt with documentation and with abuses of the existing law, including fraud and parochial efforts to export the chargeable poor as vagrants. Distinct categories of vagabond also emerged in the 1744 legislation: 'idle and disorderly persons', rogues and vagabonds, and incorrigible rogues, with increasingly harsh punishments reserved for each. ${ }^{20}$ Counties also began to contract out the conveyance of vagrants in an effort to control costs, a subject which Audrey Eccles has examined in some detail. ${ }^{21}$ This system of contractual passing and parish rates remained in force until the New Poor Law of 1834, and readers will find evidence of the operation of this conveyance system in the articles in this volume by Tim Hitchcock and Audrey Eccles.

Just who was affected by this judicial framework? For A. L. Beier, vagrants represented 'a new social problem'. They were a 'large landless element with no firm roots and few prospects', a definition that could also easily be applied to the mobile labouring poor. ${ }^{22}$ Disconnected from traditional structures of land tenure, or pursuing distrusted, ambulatory trades and professions, vagrants became emblematic of social disorder, and solving the vagrancy 'problem' preoccupied contemporaries for over two centuries. ${ }^{23}$ However, the vast majority of those taken up for vagrancy between 1600 and 1800 were actually poor people in search of work, or subsistence migrants caught in the machinery of the settlement laws. There are also some striking subgroups, including single mothers or solitary pregnant women, servants without passes, the lame and infirm, and Scottish and Irish subsistence migrants. Opportunistic petty theft and roadside begging characterise the makeshift criminality of vagrants when they were not arrested for simply entering a parish or town. And although vagrancy is historically easier to examine in an urban context, rural communities, especially those on roads between cities, could and did have their own experience of such subsistence mobility. ${ }^{24}$

Contemporaries were also preoccupied with the wider cultural representation of mobility across the social scale. Authors and playwrights, from Thomas Harman and William Shakespeare to John Gay, Daniel Defoe and beyond, were fascinated by poverty and mobility. ${ }^{25}$ Shakespeare's King Lear may be the best known literary example of 'vagrant fascination', but the play was hardly unique in taking mendicancy and mobility as central premises. ${ }^{26}$ More recently, cultural historians have turned to popular literature 
and ballads as indicative of attitudes towards a wide range of historical subjects, including poverty and mobility. ${ }^{27}$ An ever-growing range of sources is thus being deployed by historians to contextualise and 'fill in the gaps' in the histories of the mobile poor. This new range and reach, and the interdisciplinary connections it demands, are on vibrant display in this special issue. We take the social and cultural history of poverty and mobility across two centuries as our subject, and each of the five articles makes innovative use of different sources and methodologies in an attempt to tell a wider story about marginalised peoples and spaces.

\section{3.}

In the first article in this collection, Julie Sanders employs cultural geography and literary criticism to examine John Taylor's Pennyles Pilgrimage as a vagrant text, in which Taylor, as plebeian poet par excellence, takes on the role of a poor pilgrim in a fascinating combination of real journey and poetic journal. ${ }^{28}$ Taylor's descriptions of 'vagrant geography' are rich with implication and meaning, oscillating between the migratory self-sufficiency of literary beggars and the real pains of the poor traveller which he himself experiences in some small measure. ${ }^{29}$ Sanders identifies an interest in the 'choreography of poverty' in Taylor's work, 'mapping a life on the road and its encounters, audiences, pauses, staging posts, and salient events'. Taylor deliberately casts himself as both poor and mobile, even though, or perhaps because, his subsequent paean to the hospitality of various innkeepers and householders is at heart an ambitious commercial venture. Sanders concludes that Taylor's pilgrimage can tell us a great deal about 'the ways in which poverty and transience were imagined in this period' and the complex geographies of culture, space, and sociability which overlay this mental landscape.

Audrey Eccles' article examines the largely neglected links between early modern vagrancy, and 'madness' or mental illness. Here we find a single woman attempting to infect her own child with smallpox in order to undertake a biological attack on the parish which excluded her, and a mad Irishwoman who was dropped off at the house of a vagrant contractor one evening in 1780 and then disturbed the house until half past four in the morning. Sometimes vagrant lunatics came with children in their care, or even with fairly substantial wealth. No two cases seemed the same. Eccles thus problematises the early modern definitions of madness and insanity in her assessment of the many and varied cases in her research. The article also undertakes the very important work of uncovering the experiences of thoroughly marginalised and mobile people, and the local and judicial responses to the 'furiously mad' and their impact on real lives.

John Gilmore writes on the cultural perceptions of beggars found in eighteenth-century Latin poetry. However, his story begins with one of the last plays put on before the parliamentary closure of London's theatres in 1642: Richard Brome's A Foviall Crew: $\mathrm{Or}$, the Merry Beggars. Gilmore's examination of an elite set of sources describes a high level of interplay between the conceits of the thoroughly educated and erudite English elite, and the concerns of a wider literate public. Despite being largely a male preserve, translating and contextualising Latin verse allows Gilmore to chart the navigation of powerful cultural ideas of deception and beggary across the literary spectrum. Moreover, 
his article offers original translations of several Latin poems, including examples from the Carmina Quadragesimalia, a 1723 collection of exercise poems by students at Oxford. The poor and mobile emerge from these poems as 'Irus', a beggar in Homer's Odyssey who is known for deception and gluttony. Finding the beggar classicised in such unflattering terms is not surprising, but Gilmore adeptly charts the slow changes in elite attitudes over the eighteenth century, highlighting the very early romanticising of the 'jovial beggar' figure in the work of Vincent Bourne (1694-1747).

Tim Hitchcock looks at the seminal and unique events behind London's 'vagrancy crisis' in the 1780s. The crisis began with the end of 'Transportation to America in 1775 and became increasingly serious following the destruction of Newgate prison during the Gordon Riots of 1780 which directly targeted the prisons of London and included assaults on the Fleet Prison and the Kings Bench. This precipitated a full blown 'carceral crisis' which, Hitchcock argues, forced the city of London to reassess how vagrants were treated. In effect this led to the creation of a system of hospital care and transport for thousands of the migratory poor instead of punishment. At the same time, houses of correction were required to house those accused or convicted of felonies. Hitchcock charts the growth of, and problems for, the vagrancy system prior to the 1780 s, and then mines the many records of London's judicial apparatus to explain the remarkable changes in the operation of the vagrancy laws in the 1780s. The city of London continued to arrest and remove vagrants, but it seemed to have 'given up its legal obligation to punish them'. Hitchcock also suggests that the poor used this new system for their own benefit, in effect welcoming arrest and conveyance away from London as a means of free transport back to their parishes of settlement.

Finally, Keith Snell provides a fascinating look at the migrant poor in English landscape painting before 1900, combining art history and social history to great effect. Snell describes how the poor in the early eighteenth century could be 'well placed' in the domesticated English landscape: ordered and orderly, overseen by the country gentleman in all his propertied relaxation, and how the migrant poor slowly came to be 'out of place' in subsequent disquieting works of art, particularly in the work of George Morland (17631804). Snell argues that the migrant poor literally became 'far more visible' in the work of English landscape artists as the eighteenth century progressed, and that they also became increasingly separate from, and threatening to, their social superiors. Snell begins with a painting by Edward Haytley from 1744 depicting the controlled, immobile, typologised labouring poor and ends with several paintings of migrant and gypsy families, suggesting the dangers of subsistence migration. We find manifestations of the precarious position of the mobile poor in eighteenth- and nineteenth-century England throughout these articles, expressed through the pretensions of elite consumers to 'own' artistic likenesses of the poor, and through direct control of the spaces through which they moved.

Readers concerned not just with poverty and migration, but also with early modern literature, popular and elite attitudes and cultural preoccupations and the social history of the mad, the liminal, and the silent, will find much of value in this collection of essays. The social and cultural history of the 'unsettled', poor and mobile, and its literary and artistic representation, has much yet to tell us about the lives, preoccupations, and concerns of English men and women of all 'sorts' between 1600 and 1850. The stories of the vagrants, 
so long dispossessed of agency and deprived of an historical voice, take a central place and the act of recovering these stories remains the task of the social humanities everywhere.

\section{Notes}

1. The Merry Beggars of Lincolns-Inn-Field: Or, The Beggers Art to get Money, To the Tune of A Begging We Will Go (London: Printed for C. Dennisson at the Stationers Arms within Aldgate, [1685-1688]), Pepys Collection 4.252. Accessed online using the English Ballad Broadside Archive http://ebba.english.ucsb.edu.

2. See John Locke's proposed treatment of the mobile poor in his Essay on the Poor Laws, in Mark Goldie, ed., Fohn Locke: Political Essays (Cambridge, 1997).

3. Tim Hitchcock, "'All Besides the Rail, Rang'd Beggars Lie”: Trivia and the Public Poverty of Early Eighteenth-Century London', in Clare Brant and Susan E. Whyman, eds, Walking the Streets of Eighteenth-Century London: Fohn Gay's Trivia (1716) (Oxford, 2007), pp. 74-89, p. 80 .

4. For the robust and still growing 'rogue studies' literature, see Linda Woodbridge, Vagrancy, Homelessness and English Renaissance Literature (Chicago, 2001); Craig Dionne and Steve Mentz, eds, Rogues and Early Modern English Culture (Ann Arbor, 2004). For an example of an interdisciplinary perspective on vagrancy and an account of the theoretical term 'unsettled', see Patricia Fumerton, Unsettled: The Culture of Mobility and the Working Poor in Early Modern England (London, 2006). For an interdisciplinary example of cultural geography and literary criticism in the seventeenth century, see Andrew McRae, Literature and Domestic Travel in Early Modern England (Cambridge, 2009).

5. See J. F. Pound, Poverty and Vagrancy in Tudor England (Harlow, 1971). Social histories of migration became more common in the 1980s. For England see, for example, David Souden and Peter Clark, eds, Migration and Society in Early Modern England (London, 1987).

6. See A. L. Beier, Masterless Men: The Vagrancy Problem in England, 1560-1640 (London, 1985); Paul Slack, Poverty and Policy in Tudor and Stuart England (New York, 1988). For the later period see K.D.M. Snell, Annals of the Labouring Poor: Social Change and Agrarian England, 1660-1900 (Cambridge, 1985). For parish poverty and the social history of rural poverty see the work of Steve Hindle, particularly On the Parish? The Micro-Politics of Poor Relief in Rural England, 1550-1750 (Oxford, 2004).

7. Beier, Masterless Men, p. xix.

8. Constable's presentments, a major and important source for the history of vagrancy, almost cease after the Restoration, and although the Act of Settlement (1662) provides historians with a new body of evidence in the form of settlement documentation, this was not explicitly geared towards vagrancy. Vagrant passes and examinations rarely survive outside London before about 1744, when authorities began to keep second copies of both for administrative purposes. Quantitative work is thus far more difficult to pursue in this period.

9. See the work of Tim Hitchcock, including 'Begging on the Streets of Eighteenth-Century London', Fournal of British Studies, 44: 3 (2005), 478-98, and Down and Out in EighteenthCentury London (London, 2004). Another recent work that is worth consulting is Paul Griffiths, Lost Londons: Change, Crime, and Control in the Capital City 1550-1660 (New York, 2008). On vagrant conveyance and contracting, see Audrey Eccles, 'The Adams' Father and Son, Vagrant Contractors to Middlesex 1757-94', Transactions of the London and Middlesex Archaeological Society, 57 (2007), 83-91.

10. The law in Edward III's reign was 23 Ed. 3. See Richard Burn, The History of the Poor Laws, with Observations (Originally Published in 1764), then reprinted (Clifton, 1974). For the 1572 law, see 14 Eliz. C5., in Fournal of the House of Commons: May 1572, in Sir Simonds d'Ewes, ed., The Fournals of all the Parliaments during the Reign of Queen Elizabeth (1682), pp. 205-221. Accessed online via British History Online.

11. 39 Eliz c4. in 1597; 43 Eliz c2. in 1601;1 James c77. in 1604. 
12. Quoted from 39 Eliz. c4., in Statutes of the Realm, Volume IV, Part 2 (1819), p. 899, and in Philip Styles, Studies in Seventeenth Century West Midlands History (Kineton, 1978), p. 177.

13. Styles, Seventeenth Century West Midlands History, p. 176.

14. 14 Charles II c12. in John Raithby, ed., Statutes of the Realm: Volume 5, 1628-80 (London, 1819)

15. See Peter Clark's chapter in David Souden and Peter Clark, eds, Migration and Society in Early Modern England.

16. See K. D. M. Snell, Parish and Belonging: Community, Identity, and Welfare in England and Wales, 1700-1950 (Cambridge, 2006).

17. For a primary example, consult the judicial handbook of Paul D'Aranda in manuscript. Kent Country Record Office (KCRO), Ps/Se/1 Sevenoaks Petty Sessions 1708-1710, ff. 15-30.

18. $11 \& 12$ William III c18. in John Raithby, ed., Statutes of the Realm: Volume 7, 1695-1701 (London, 1820).

19. 13 Anne c26. in Statutes of the Realm.

20. 17 Geo II c5. in Charles Runnington, ed., The Statutes at Large, from Magna Charta, to the Twenty-Fifth Year of the Reign of King George the Third, Volume 6 (London, 1786). Accessed online via Eighteenth Century Collections Online (ECCO).

21. Audrey Eccles. 'The Adams' Father and Son', pp. 83-91.

22. Beier, Masterless Men, p. xxi.

23. For an example of a large and growing trade that was deeply distrusted, see Margaret Spufford, The Great Reclothing of Rural England: Petty Chapmen and their Wares in the Seventeenth Century (London, 1984).

24. For a recent and very successful example of reconstructing urban vagrant lives, see Tim Hitchcock, 'Vagrant Lives' in Joanna McEwan and Pamela Sharpe, eds, Accommodating Poverty: The Housing and Living Arrangements of the English Poor, c. 1600-1850 (Basingstoke, 2011). For rural vagrancy, see Joan Kent, 'Population Mobility and Alms: Poor Migrants in the Midlands During the Early Seventeenth Century', Local Population Studies, 27 (Autumn, 1981), 35-51, and also David Hitchcock, 'A Typology of Travellers: Migration, Justice and Vagrancy in Warwickshire, 1670-1730', Rural History, 23:1 (2012), 21-39.

25. See Thomas Harman, A Caveat for Commen Cursetors Vulgarely called Vagabones, set forth by Thomas Harman, esquiere, for the utilite and proffyt of his naturall cuntrey (London, 1567), accessed online via Early English Books Online, and John Fuller, ed., Fohn Gay: Dramatic Works, Volume II (Oxford, 1983), pp. 1-66, for the Beggar's Opera with editorial commentary.

26. Woodbridge's chapter on King Lear in Vagrancy, Homelessness and English Renaissance Literature is particularly incisive. Other authors who have looked at similar themes include: Paola Pugliatti, Beggary and Theatre in Early Modern England (Aldershot, 2003), and William C. Carroll, Fat King, Lean Beggar: Representations of Poverty in the Age of Shakespeare (Ithaca, 1996).

27. Published work on ballads directly about early modern roguery have not yet made an appearance, but for examples of how historians have used ballads to discuss other subjects see Tessa Watts, Cheap Print and Popular Piety, 1550-1640 (Cambridge, 1991). For marriage, see James A. Sharpe, 'Plebeian Marriage in Stuart England: Some Evidence from Popular Literature', Transactions of the Royal Historical Society, 36 (1986), 69-90. For a wider survey of the implications and meanings of popular literature, see Adam Fox, Oral and Literate Culture in Early Modern England, 1500-1700 (Oxford, 2000).

28. See Julie Sanders, The Cultural Geography of Early Modern Drama, 1620-1650 (Cambridge, 2011).

29. For self-sufficient beggars, see John Taylor, The Praise, Antiquity and Commodity of Begging (London, 1621), and for his own journeys, see John Taylor, The Pennyles Pilgrimage or The Money-lesse Perambulation (London, 1618). Andrew MacRae has a chapter on Taylor and space in Literature and Domestic Travel in Early Modern England (Cambridge, 2009). 